\title{
Narrative and the Substance of Architectural Spaces: The Design of Memorial Architecture as an Example
}

\author{
By Ching-Pin Tseng*
}

The causality between function and architectural form was an orthodox factor in the process of architectural design, as well as a determinant for the discourse of spatial content in functionalist architecture, yet, by the 1950s, this doctrine of modern architecture was challenged by a changing social context. In the discussion of the relation between the formal elaboration of spaces and the setting of programmes, Bernard Tschumi explores the constant interaction and correlation between the formal construction of spaces and the complex activities and events that take place within them. On that account, the paper argues that the creation of architectural spaces and meaning may not necessarily rely on causal relations with function or conventional programme. In terms of the design of memorial architecture, it is essential to re-examine what spatial content can be and how this content can be generated, or what thing can be thought of as the substance of the architecture. Because narrative is related to events or stories that have happened or have been happening in cities and in our everyday lives, it can be suggested that the construction of narrative in architecture may stem from people's collective memories of historical events, events in an urban context and urban experiences, from which the content of architectural projects or spatial implications can be generated. The paper will thus explore the sources of spatial narratives as well as the means of introducing and transforming narratives into architecture through the study of some select memorials, Daniel Libeskind's Berlin Jewish Museum and the Imperial War Museum in Manchester, for example. In the former museum, the architect intends to convey the history and memory of Jewish people and the Holocaust mainly through architectural compositions and their spatial languages. It is thus important to discuss the relationship between the construction of spatial narrative and the substance of architectural spaces. As narrative is an abstract composition of past events or images of related places, the paper will finally discuss how narratives or memories can be represented through spatial languages and representational media, and what the limit of the visitor's spatial interpretation of the related narratives will be.

\footnotetext{
*Assistant Professor, National Sun Yat-sen University, Taiwan.
} 


\section{Introduction}

In the process of architectural design, the design brief or programme is a determinant factor for the architect to follow in the construction of his/her spatial ideas. This design programme is a document composed of the quantitative requirement of the client and the spatial need of the user, as well as the description of spatial organization and spatial characteristics. In discussing historical aspects that determine the notion of the programme, Tschumi states that '...the program long remained an important part of the architectural process', although the eighteenth century's development of scientific techniques and most beaux arts programmes emphasised 'pure formal manipulation' and regarded 'use and construction as separate disciplines'. This disjunction between "form" and "content", however, which also resulted from the nineteenth-century's complex programme and the requirement of ideal building types, was attacked by the modern movement. ${ }^{2}$

The causality between function and architectural form was an orthodox factor in the process of architectural design, as well as a determinant for the discourse of spatial content in the functionalist architecture. By the 1950s, however, this doctrine of modern architecture was challenged by a changing social context. In terms of the relation between the formal elaboration of spaces and the setting of programmes, Bernard Tschumi explores the constant interaction and correlation between the formal construction of spaces and the complex activities and events that take place within them. That is, Tschumi's research on space and its content can be related to the correlation between the language aspect of spatial form and narratives in the space. In relation to the relationship between literary narrative and architecture Tschumi suggests that 'the unfolding of events in a literary context inevitably suggests parallels to the unfolding of events in architecture. ${ }^{3}$ This argument reveals not only the multiplicity of spatial contents and the interdisciplinary approach of design thinking, but also the importance of exploring events or narratives in architecture. The paper thus argues that the creation of architectural spaces and meaning may not necessarily rely on causal relations with function or conventional programme.

As narrative is related to events or stories that had happened or have been happening in cities and in our everyday lives, the paper suggests that the construction of narrative in architecture may stem from people's collective memories of historical events, events in an urban context and urban experiences, from which the content of architectural projects or spatial implications can be generated. For the study of the relationship between architectural space and its content, the paper will firstly discuss the relationship between architecture and narrative in terms of 'architecture as the venue of narratives' and 'architecture as narrative' in traditional context. To further

\footnotetext{
${ }^{1}$ Tschumi, Bernard. 1999. Architecture and Disjunction. The MIT Press, Cambridge and London, p. 113.

${ }^{2}$ ibid., p. 114.

${ }^{3}$ Tschumi, Bernard. 1990. Questions of Space. Architectural Association, London, p. 92.
} 
explore the connection between narrative and the content of architecture, it is essential to discuss the potential means of introducing narratives into architecture and the construction of spatial narration.

As the design of memorial architecture focuses on remembering someone or an important past event, the paper thus intends to study the content of this sort of architecture, as well as the relationship between the related events or narratives and the design of the architecture. In the design of memorial architecture, the study of historical narratives plays an important role to the creation of symbolic spaces and the formation of spatial narration. Accordingly, the paper will study two important projects, namely the Jewish Museum in Berlin and the Imperial War Museum in Manchester, that were designed by Daniel Libeskind, because of the related momentous historical events and the projects' unique ways of spatial narration. In these museums or memorial constructions, the architect intends to convey the memories and the happenings of specific events mainly through abstract architectural spaces and their spatial relations to the historical events. It is thus important to discuss what spatial content of the memorial constructions can be, and how the content of these memorials can be generated. As narrative is an abstract composition of past events, moreover, through the discussion of these select projects the paper will finally discuss how narratives or memories can be represented through spatial languages and representational media, and what the limit of the visitor's spatial interpretation of the related narratives will be.

\section{Narrative Architecture in Traditional Context}

Although "narrative" and "architecture" are two different subjects or disciplines, the study of narrative in architecture or the construction of narrative architecture has been a long history. To explore the relationship between narrative and architecture as well as the construction of narrative in architecture, some historical precedents can be discussed. In other words, the section will discuss how narratives are presented in architectural spaces or conveyed by architectural elements and spatial languages, as well as exploring how architectural drawings can portray narratives in historical context.

In terms of the conveyance of narratives in architecture in traditional context, firstly 'architecture as the venue of narratives' focuses on the objective role of architectural space and its scenic setting for theatrical plays. Secondly, 'architecture as narrative' aims to discuss the potential of spatial narration by architecture itself and which can be fulfilled by spatial language.

\section{Architecture as the Venue of Narratives}

In Athens a theater, dating from the early sixty century BC, ...They were associated with the frenzied rituals in honour of Dionysus and had to be large enough to include a circular or semicircular stage, ... for the chorus and the dancing involved in the rituals, an altar for the libations with which performances commenced ... It was here that Aeschylus, Sophocles, Euripides 
and Aristophanes presented their plays, laying down the pattern for Western drama and theatre.

With architectural setting and spatial spectacle, Greek theaters were venues for characters to perform classical plays and to convey theatrical narratives. This sort of architecture is not a subject element for generating narrative discourse, but a place for providing spatial capacity for the actor (actress) to deliver narratives. It can be seen that a Greek theater can be regarded as a narrative background on which narrative characters and scenario are presenting. This role of narrative background is similar to the spatial settings in architectural drawings in Renaissance period.

Architectural drawings that were used to represent narratives in Catholicism or Christianity were developed in the middle ages. For instance, Nicholas Penny states that ' $[\mathrm{t}]$ he artist had to devise architecture, fitting for Mary, which was open not only to our view but to the passage of the divine agent - beautiful, domestic, private; and miraculously penetrated' 5 In Duccio's little panel The Annunciation (Figure 1), Penny says that 'the architecture participates in the narrative, so closely are the rhythms of the springing of the arches and the divisions of their supporting piers related to the movement of the figures'. ${ }^{6}$ In this pictorial space, in order to portray the narrative, the rhythm of the springing of the arches corresponds to the action of figures and presents as an important factor of the scene. To compare Duccio's and Domenico Veneziano's The Annunciation (Figure 2), it can be seen that in Veneziano's The Annunciation, perspectival space and vanished point cannot correspond to the action of figures, but direct our view to the inner garden and its locked door, which suggests the connotation of this narrative. As Nicholas Penny states '[t]his garden with its locked door is for him equivalent to the vase of lilies which in the Duccio painting are symbolic of the Virgin's purity, $\ldots$... The above-mentioned examples demonstrate the role of architectural spaces in presenting theatrical narratives and religious stories. Due to the specific rituals and symbolic meaning, the spaces are not independent of their plots and characters for expressing the stories. Although 'the rhythms of the springing of the arches' and 'the inner garden and its locked door' imply spatial meaning, their scenic characteristics are stronger than the role of narrative expression.

\footnotetext{
${ }^{4}$ Nuttgens, P. 1983. The Story of Architecture. Phaidon Press, Oxford, p. 93.

${ }_{5}^{5}$ Penny, N., 1990. Architecture, Space, Figure and Narrative. AA Files. 20 (Autumn, 1990), p. 34-41.

6ibid.

${ }^{7}$ ibid.
} 
Figure 1. Duccio. 1311. The Annunciation (National Gallery, London), in Penny, N. 1990, p. 34

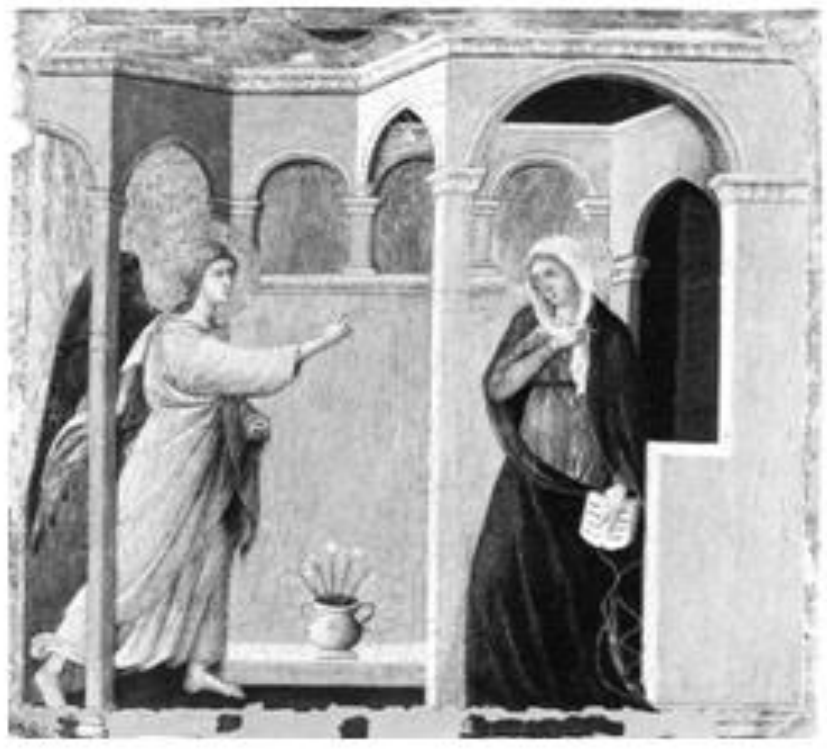

Figure 2. Veneziano, Domenico. 1445-7. The Annunciation (Fitzwilliam Museum, Cambridge), in Penny, N. 1990, p. 35

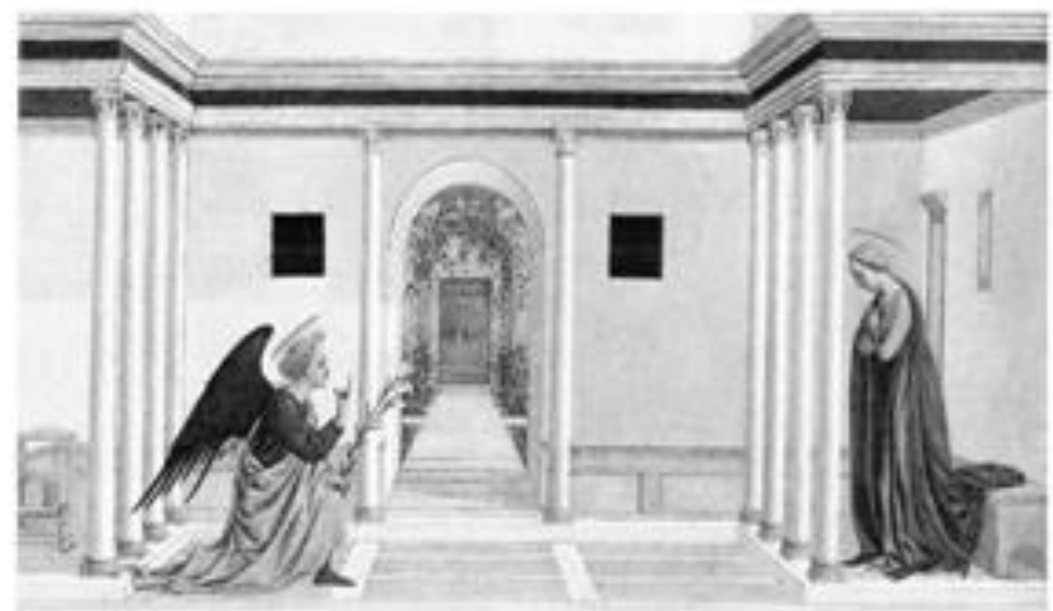

\section{Architecture as Narrative}

In relation to the self-expression of human will of language and architecture, Adrian Forty states:

For Goethe, architecture was like language in that it provided immediate expression of man's intellect and spirit. At the same time, again following Herder, Goethe saw that architecture, like language, was not simply a medium of individual expression, but more importantly expressed the entire collective identity of particular peoples, the Volksgeist. ${ }^{8}$

\footnotetext{
${ }^{8}$ Forty, Adrian. 2000. Words and Buildings. Thames \& Hudson, London, p. 76.
} 
According to Forty's discussion and Goethe's assertion that architecture does not only like a language for the architect's or the user's personal expression but also can demonstrate collective identity of certain peoples, it can be argued that architecture may present as narrative, demonstrating collective memories and characteristics through spatial and material languages. In order to clarify how traditional architecture bears meaning and presents as narrative, it is essential to discuss this through two approaches.

\section{Architecture Expresses Commentaries or Narrative Meanings}

Sebastiano Serlio was an important writer on architecture in the sixteenth century. He proposes his social and moral commentaries through satiric drawings. In the last illustrations of Serlio's Book II (1545), there are three blocks depicting Tragic, Comic and Satiric stage scenes. In relation to how Serlio uses architectural elements to convey meanings in Tragic scene (Figure 3), John Onians states:

... such lofty characters are given an appropriate background with all the apparatus of arcades and colonnades, pediments and niches, sculpture and inscriptions. Tragic architecture is as urban and correctly Classical as Satiric architecture is rural and rustic. The lofty actions of great personages have a setting which is as disciplined and refined as that of the low actions of the peasantry is rough and disordered. ${ }^{9}$

Figure 3. Serlio, Book II: Tragic Scene (from 1551 ed., fol. 29v), in Onians, J. 1990, p. 284

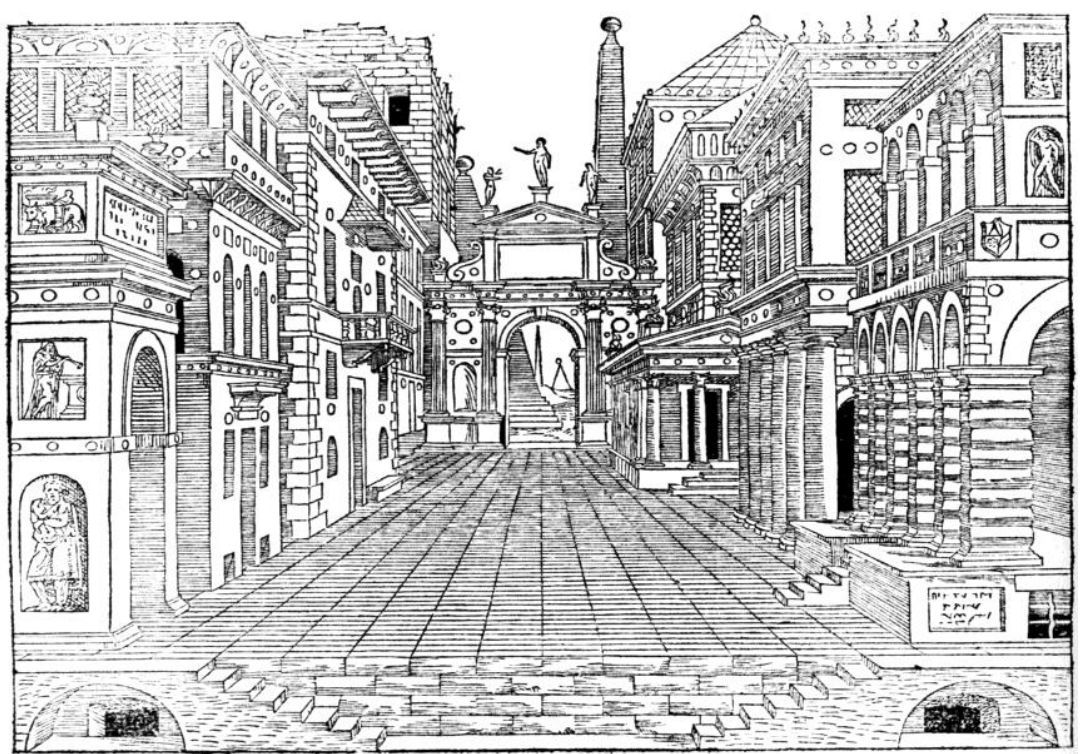

\footnotetext{
${ }^{9}$ Onians, J. 1990. Bearers of Meaning: The Classical Orders in Antiquity, the Middle Ages, and the Renaissance. Princeton University Press, Princeton, New Jersey, Chichester and West Sussex, p. 284.
} 
It can be seen that the refined spatial composition and classical architectural elements suggest the civilised manners of noble people on the one hand, but imply the concealment of their abnormal private lives on the other. In terms of the spatial expression and narrative meanings showed in the Comic scene (Figure 4), differentiated spaces and various living requirements suggest the multiple and unrefined life style of private people. That is, the disordered spatial characteristics of the Comic scene correspond to the diversity and freedom of normal citizens. Although the perspectives present two static spatial phenomena, the spatial characteristics in the drawings clearly illustrate the living scenarios of the two varied classes. It can be stated that architectural spaces composed in these two scenes convey not only the different collective images and living styles of the people, but also the satiric meanings that Serlio would like to portray.

Figure 4. Serlio, Book II: Comic Scene (from 1551 ed., fol. 28v), in Onians, J. 1990, p. 285

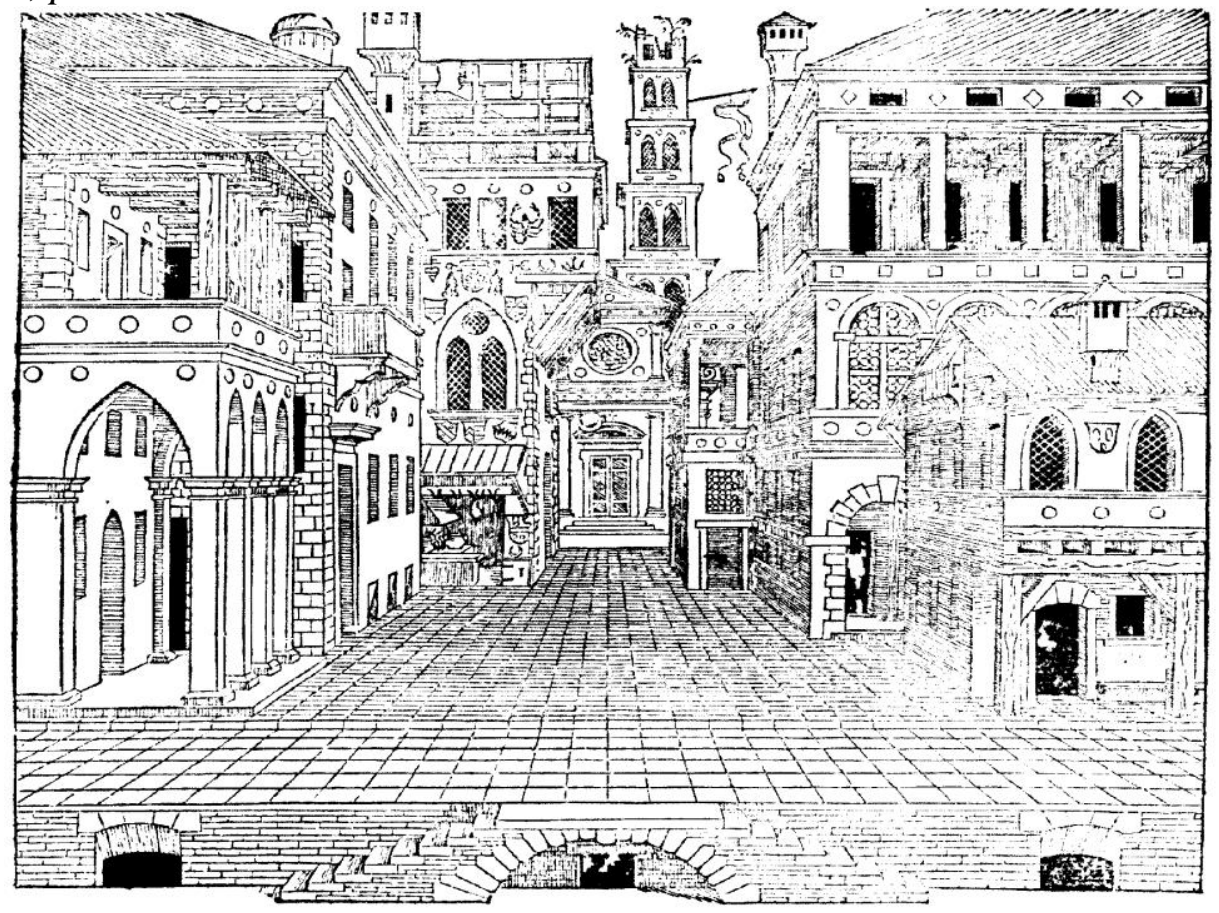

\section{Architecture Records Stories and Embodies Narrative}

In many traditional buildings, stories regarding a specific religion were inscribed on the surfaces of spatial elements so as to deliver religious meanings. The Bible can be one of the earliest textural narratives, which conveys religious doctrine with Christian stories. In the investigation of narrative in architecture, it is important to discuss how the stories of the Scripture are presented by sculptures, paintings and reliefs in cathedral, together with their spatial representation. In discussing the relationship between articulation and embodiment of architecture in Chartres the cathedral, 
Dalibor Vesely clearly describes the meaning of the west façade of the cathedral. (Figure 5) Vesely states:

Its primary theme is the Last Judgment, centered on the figure of Christ in his second coming (Parousia). The Parousia of Christ is the final stage of his coming, which began with the incarnation of the word, continued with his descent into death, and will end in the resurrection and the outpouring of the light that completes the transformation of the world. ${ }^{10}$

With respect of the relationship between the location of the Last Judgment and the symbolism of light, Vesely says:

It is interesting to note that at Chartres the Last Judgment was elevated to the upper part of the façade and thereby incorporated into the solar symbolism of the cathedral. ... In the Chartres rose window, the story of the gospel is interpreted as an image embodied in the colored glass, which is in turn embodied in the shape of the window, in the composition of the wall, and finally in the structure of the church as a whole. These embodiments also represent a corresponding sequence of articulations. The light that penetrates the colored glass reveals the different levels of the articulation most clearly. On the highest level, light is the visible manifestation of its invisible source (lux), which is closely linked with the intelligible meaning of Scripture. In a less elevated sense, light shows itself in the luminosity of the terrestrial elements and as a mystery of incarnation. Finally, on the lowest level, light demonstrates the ambiguity of shadows and the disappearance of light in the impenetrability of matter. ${ }^{11}$

Because of the orientation of the cathedral, the stories presented in the window and 'their embodiment in the hierarchical structure of the cathedral' are 'animated by the movement and light of the sun'. ${ }^{12}$ Furthermore, the culmination of light in the sunset implies the invisible phenomena of death and the resurrection of the Christ. In this example, architecture not only provides a background for visualizing the narrative, but also articulates its implied meaning through the spatial structure and building materials, as well as the manifestation of light. The symbolic meaning delivered by Chartres cathedral can be embodied and emphasized by the projection of light and can be perceived at certain moments by a clear understanding of the story of 'the Last Judgment'.

\footnotetext{
${ }^{10}$ Vesely, D. 2004. Architecture in the Age of Divided Representation: The Question of Creativity in the Shadow of Production. The MIT Press, Cambridge and London, p. 64.

${ }^{11}$ ibid., p. 64, 66.

${ }^{12}$ ibid., p. 67.
} 
Accordingly, it can be stated that narrative in architecture in historical context expresses symbolic meanings of certain religious context and specific references through classical architectural elements and symbolic forms. Architectural space itself functions as background for holding religious ceremonies or rituals on the one hand, and acts as foreground for demonstrating religious narratives because of its figurative paintings (sculptures) and spatial composition on the other. The viewer may not grasp multiple meanings of the narratives through this spatial representation. Furthermore, the perspective drawings in the above-mentioned examples dominate our viewpoint and imply a fixed reading of religious narratives. In the following section, issues regarding narrative architecture in contemporary context and its means of representing multiple narrative meanings will be discussed further.

Figure 5. Chartres Cathedral, West Front, in Vesely, D. 2004, p. 65

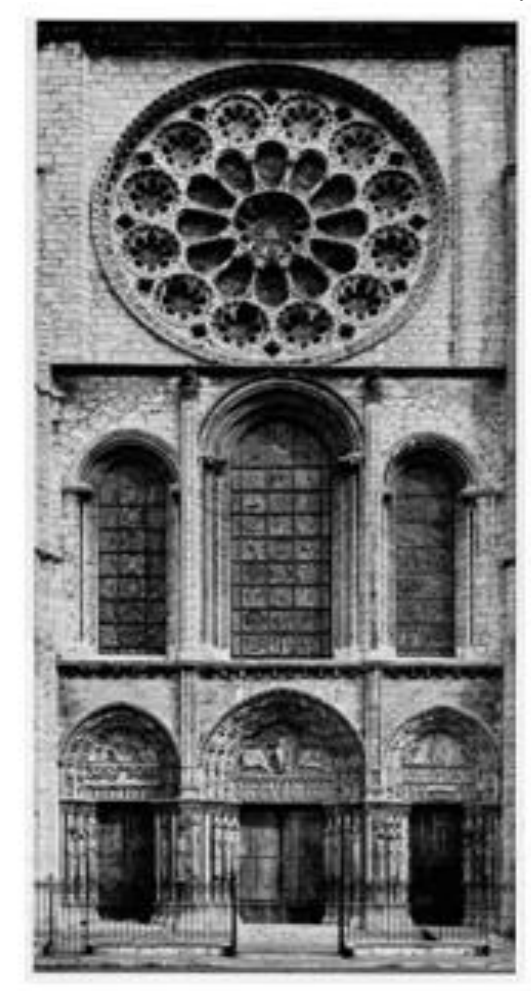

\section{Narrative Architecture and its Contemporary Approach}

In relation to narrative architecture in contemporary context, it may need to discuss how architecture can convey narratives and what architecture's content can be, how this content can be generated or what thing can be thought of as the substance of architecture. In this informational age, the means of communication has changed and its multiplicity has redefined our spatial dimension as well as our perception of the modern environment. With respect 
of the role of architecture in the software age, Nigel Coates, a chief member of NATO (Narrative Architecture Today), states:

Meaning and conventional function need not necessarily be linked. Buildings need to coax people back into working with them rather than against them ... they need a time dimension, a mental dimension ... or what we could call narrative. ${ }^{13}$

According to Coates's perspective, in order to draw forth human considerations in architecture and to reflect on our bodies' reaction to the complex software, age, narrative and a time dimension along with the mental dimension, which are all related to the nature of human experience, need to be introduced into the process of architectural design and its means of representation.

In considering that the construction of narrative in architecture may stem from people's collective memories of historical events and events in urban context, this section will study two memorial projects related to momentous events that had happened in history. These projects are "The Berlin Jewish Museum" and "The Imperial War Museum, Manchester" both by Daniel Libeskind. The content of architectural projects in this approach can be thought of as the substance of spaces rather than buildings' functional concerns, which may temporarily and spatially integrate with the explicit and implicit situations of a city as well as interweaving with people's collective memories or experiences. In the paper, the substance could be thought of as the communicative media between the user and architectural spaces, with which events in a city and peoples' collective memories could be associated with the expression of spatial narrations.

To clarify the relationship between narrative and the content of architecture, two viewpoints regarding narrative in architecture will be discussed. One is "conveying memory through the void"; the other is "architecture as a resonator of memory".

\section{Conveying Memory through the Void}

If memory can be recollected, would any relative source be gathered and be used for recalling its essence and further could the recalled objects or images be represented by means of spatial constructions? The Berlin Jewish Museum is a project designed to convey the history and memory of Jewish people in Berlin as well as the deportation of its citizens and the victims of the Holocaust. Daniel Libeskind, the architect who designed the Jewish Museum (Figure 6), states that there are three basic ideas that form the foundation for the design of this museum. One of the ideas is that:

\footnotetext{
${ }^{13}$ Coates, Nigel. 1988. Street Signs. In Thackara, John, Ed. (1988), Design after Modernism. Thames and Hudson, London, 95-114, p. 99.
} 
...only through the acknowledgment and incorporation of this erasure and void of Jewish life in Berlin, can the history of Berlin and Europe have a human future. ${ }^{14}$

To Libeskind, one of the lines of thinking in this museum is 'a straight line, but broken into many fragments'. ${ }^{15}$ This line creates a series of 'voids', in which there is nothing. In other words, Libeskind's endeavour to represent the invisibility of the exiled Jewish Berliners and the victims of the Holocaust can be conceived from the project's succession of 'voids' that are illuminated by skylights and which signify something which cannot be exhibited in this museum. Moreover, the void space in the Holocaust Tower (Figure 7) expresses deadly spatial phenomenon with 'the only light filtering down came from a slit in the roof that was barely visible from below'. ${ }^{16}$ This void can be freely interpreted by visitors' basic understanding of the Holocaust; something must be there, but it is difficult to see or touch.

Figure 6. Libeskind, Daniel. 1999. The Main Staircase of the Berlin Jewish Museum, Berlin, Germany. Photograph, Tseng, $C-p$

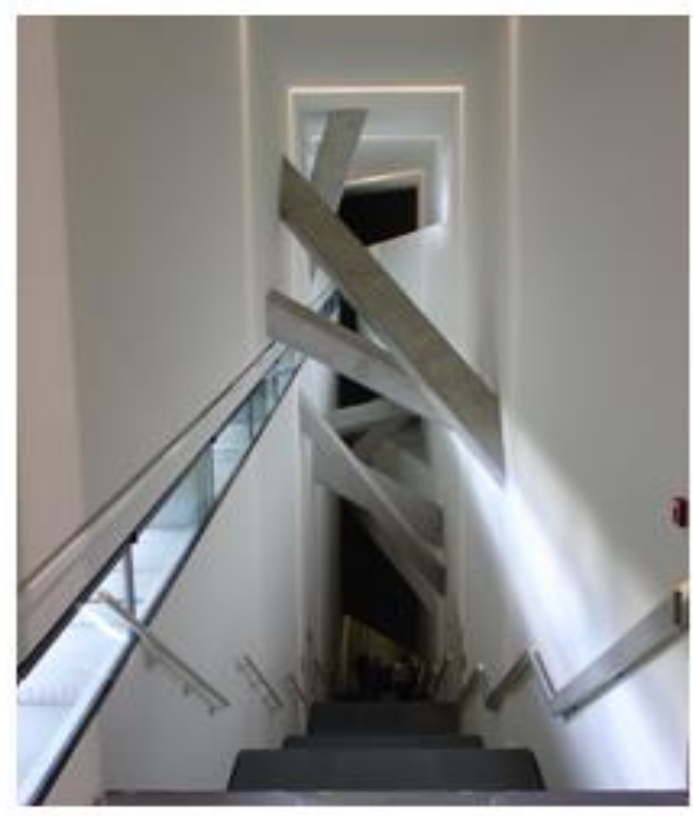

\footnotetext{
${ }^{14}$ Libeskind, Daniel. 2001. Daniel Libeskind: The Space of Encounter. Thames \& Hudson, London, p. 23.

${ }^{15}$ ibid.

${ }^{16}$ Libeskind, Daniel. 2004. Breaking Ground: Adventures in Life and Architecture. John Murray, London, p.84.
} 
Figure 7. Libeskind, Daniel. 1999. The Void of the Holocaust Tower in the Berlin Jewish Museum, Berlin, Germany. Photograph, Tseng, C-p.

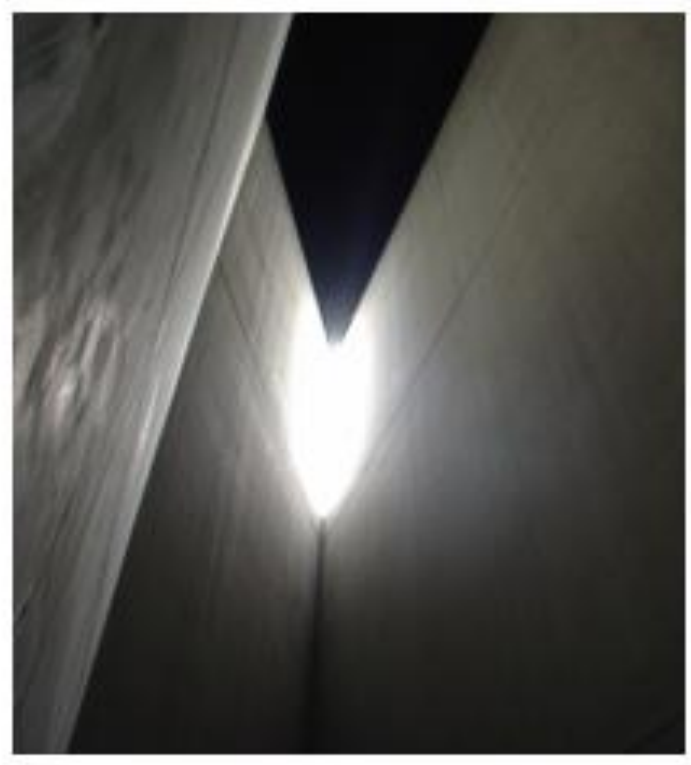

In the Berlin Jewish Museum, the concept of the void is not only represented spatially but also psychologically. Furthermore, Libeskind says that when visitors intend to cross from one space of the museum to the other, they need to traverse sixty bridges that open into the void space that is the embodiment of absence. ${ }^{17}$ The void representing the discontinuity of the history of Jewish Berliners, moreover, suggests not only the embodiment of absence but also a place for meditation and a spatial container for introducing natural light to illuminate the darkness of memory, which may further contribute to the flexibility of the visitor's spatial interpretation. The design of this museum intends to realise a new relationship between programme and architectural space. That is, the void space presents as an objective spatial container for holding the narratives of the Holocaust, whilst simultaneously acting as a subjective character for conveying the erasure of Jewish Berliners in the Holocaust and for stimulating Jewish Berliners' and the visitor's imagination for future hope.

In association with the memory of the past and future hope, this museum could be characterised as 'in-betweenness: of incomplete translation, of past and future, memory and prophecy. ${ }^{18}$ In regard to the conveyance of spatial narratives, it can be stated that this museum may be in a dilemma as to whether to represent the ruptured consciousness and the erasure of the city's past through abstract spatial language with a series of 'voids' or to fully exhibit the city's erased memories and the Holocaust in 'the embodiment of absence'. As Libeskind states that ' $[\mathrm{t}]$ he museum is open to many interpretations and many

\footnotetext{
${ }^{17}$ Libeskind, Daniel. 2001. ibid., p. 28.

${ }^{18}$ Isenberg, Noah. 2001. The Work of Walter Benjamin in the Age of Information. New German Critique. 83, 119-50.
} 
routes $^{, 19}$, the abstract spaces and the voids of this architecture suggest prophetic and multiple imaginations. In terms of the curatorial products in the museum, it can be seen that in order to communicate an emotional and mental level to the visitor with German history and the Jewish dimension in Berlin, the exhibitions in the museum bring the reality of the Holocaust event to the visitor's spatial experience, with which the erased memories may be revealed and patched up. Although the exhibitions and the narration of the Holocaust could have created a temporal and spatial interweaving within these disorientated passages, I would argue that due to the cramming of the abstract spaces with specific exhibits and information the visitor may not be able to interpret the spatial narratives freely when viewing the exhibitions. The architectural space itself thus becomes a background (an object) of the narratives rather than a foreground (a subject).

\section{Architecture as a 'Resonator' of Memory}

In the design of the Imperial War Museum in Manchester, Libeskind employs abstract spatial languages to express the impression and experiences of the two World Wars and to convey to visitors a sense of disorientation in and after experiencing the superimposition and intervention of various exhibitions. (Figure 8) The main exhibition hall holds diverse and undefined spaces among the exhibits, through which the visitor may catch multiple pieces of information and fragmented memories of the Wars as well as experiencing certain quasi-urban encounters within these remnant spaces designed by the architect. The narratives of the World Wars are demonstrated by the presentation of a narrator together with the projection of war images, sound effects and a dramatic lighting performance as well as the spatial simulation of warfare. Architectural space itself has thus become more a background than a foreground in terms of conveying the narratives of the World Wars; or in Libeskind's words, this museum is 'the integration of architecture, exhibition design engineering, and a vision of history and the future. ${ }^{20}$ In addition to these performances the exhibitions provide a series of interactive settings, with which the fragmented images of the two World Wars are related and by which the memories of conflict can be recalled. An air shard viewing platform that is located in the entrance lobby on the one hand provides an access for visitors to have the experience of uneasiness through walking in the air; and on the other draws visitors back to reality by viewing the surroundings after (before) experiencing a series of exhibition spaces with the re-composed World War narratives and collective memories.

\footnotetext{
${ }^{19}$ Libeskind, Daniel. 2001. ibid. p.28.

${ }^{20}$ ibid., p.63.
} 
Figure 8. Libeskind, Daniel. 2001. The Main Exhibition Hall, Imperial War Museum North, Manchester. Photograph, Tseng, $C-p$

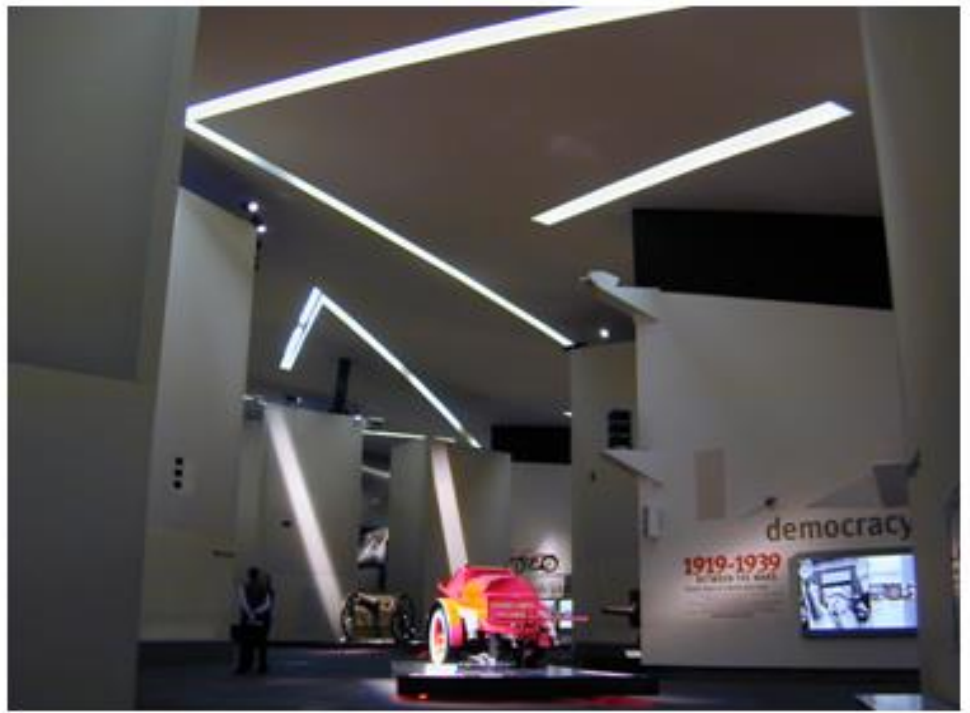

In relation to the narration of collective memories, the architectural space itself in the Imperial War Museum in Manchester is presented as a constellation of emblematic forms and functions, which arbitrarily signify the conflicts and the traces of the World Wars' history. Nevertheless, this composition of conflicting fragments or resonators of memory has accommodated multiple exhibitions within these open and flexible spaces to convey narratives of the World Wars and to recall people's experiences in the conflicts, through which the potential for the visitor to encounter unexpected events can be generated. (Figure 9)

Accordingly, the paper argues that an important concept for conveying narratives in architecture and in exhibitions is to construct a spatial 'resonator' for the spatial perception of the user. An architectural 'resonator' can be generated by transforming the scenario of narratives or the spatial aspect of narrative structure into spatial construction, so as to reflect the collective memories and provide channels for the user to take part in the interpretation of the narrative meaning imbedded in the architecture. From the viewpoint of post-structuralist narrative, I would suggest that to build up an architectural narrative, it is essential to provide a shared system for spatial users, which 'is the process of narrative production in the communal narrative-matrix' ${ }^{21}$

\footnotetext{
${ }^{21}$ Mcquillan, Martin. 2000. Introduction. In Mcquillan, Martin, Ed. (2000), The Narrative Reader. Routledge, London, p. 24.
} 
Figure 9. Libeskind, Daniel. 2001. The Projection of the Wars' Images in the Exhibition Hall, Imperial War Museum North, Manchester. Photograph, Tseng, $C-p$

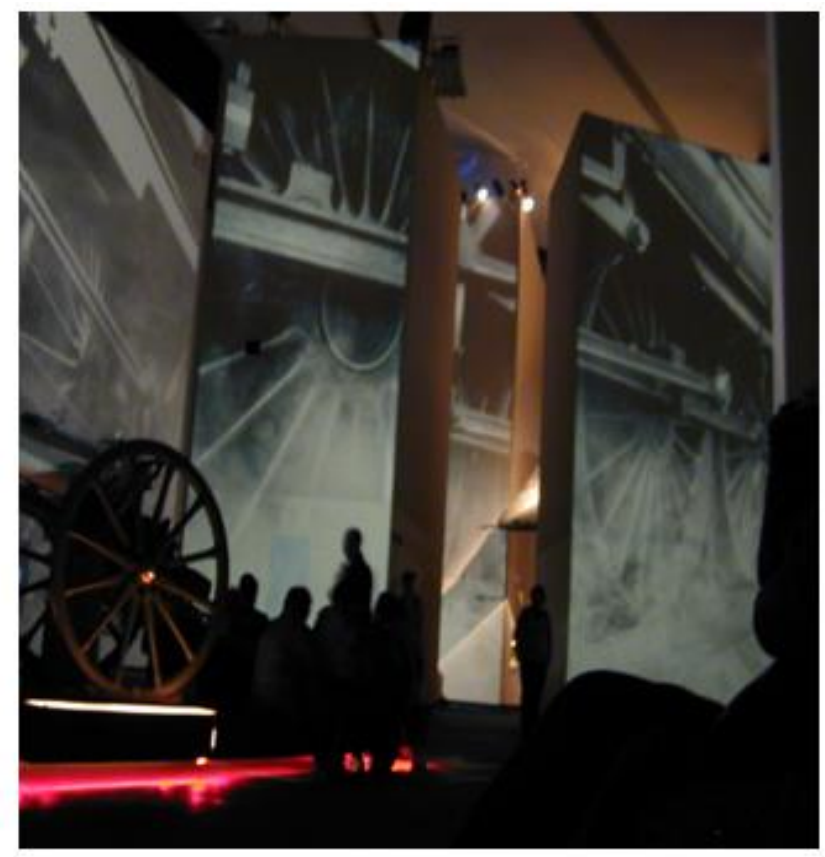

\section{Conclusions}

In terms of the design of memorial architecture, some historical traces and specific textual references regarding the momentous events have been transformed into the spatial content of the two museums. Libeskind manipulates the addresses and homes of the exiled Jewish Berliners and victims of the Holocaust into the drawing of a Star Matrix and the design process of the Berlin Jewish Museum for the configuration of its spatial construction. It can be argued that some specific narrative references of the Holocaust have contributed to the spatial representation of the history of Jewish Berliners and the people's erased memories. It is hard to state however that there are definite narrative references which have been applied to the design and construction of the Imperial War Museum in Manchester. Its historical narratives and collective memories can be grasped or be reinterpreted through the stimulation of the exhibition spaces and the multiplicity of spatial narrations. In comparison with the void spaces cut intentionally by a straight line that is connected with the historical traces of the site of the Jewish Museum, the undefined spaces between each fragmented area in the Imperial War Museum are formed without relation to the site and are shaped by the collision of geometric forms, spaces and distorted routes. A sense of disorientation that is developed by the design of dramatic spatial scenario and multiple exhibitions in the enclosed spaces has disconnected this Imperial War Museum from its site specificity. 
With respect to the composition of spatial narration, the void spaces that are constructed within the spatial and temporal matrixes of the Jewish Museum of Berlin on the one hand spatialise the Jewish people's erased memories of the Holocaust event, and on the other materialise the temporal discontinuity of Jewish history in Berlin. The paper would stress that in terms of the design of narrative architecture, Libeskind's museum projects can be thought of as a resonator of collective memory, which is shaped by abstracting the traces of historical memory, such as texts and emblematic images, and is represented by abstract and fragmented spatial constructions. Although the sources for the design of narrative architecture might vary from project to project or from architect to architect, it can be concluded that narratives of related events are important for forging the substance of memorial architecture through transforming the scenario and aura of the narratives into spatial construction whereby spatial narration can be presented and animated in association with spatial elements as well as representational media.

\section{References}

Coates, Nigel. 1988. Street Signs. In Thackara, John, Ed. (1988), Design after Modernism. Thames and Hudson, London.

Isenberg, Noah. 2001. The Work of Walter Benjamin in the Age of Information. New German Critique. 83, 119-50.

Forty, Adrian. 2000. Words and Buildings. Thames \& Hudson, London.

Libeskind, Daniel. 2001. Daniel Libeskind: The Space of Encounter. Thames \& Hudson, London.

Libeskind, Daniel. 2004. Breaking Ground: Adventures in Life and Architecture. John Murray, London.

Mcquillan, Martin, 2000. Introduction. In Mcquillan, Martin, Ed. (2000), The Narrative Reader. Routledge, London.

Nuttgens, P. 1983. The Story of Architecture. Phaidon Press, Oxford.

Onians, J. 1990. Bearers of Meaning: The Classical Orders in Antiquity, the Middle Ages, and the Renaissance. Princeton University Press, Princeton, New Jersey, Chichester and West Sussex.

Penny, N. 1990. Architecture, Space, Figure and Narrative. AA Files. 20 (Autumn, 1990), 34-41.

Tschumi, Bernard. 1990. Questions of Space. Architectural Association, London.

Tschumi, Bernard. 1999. Architecture and Disjunction. The MIT Press, Cambridge and London.

Vesely, D. 2004. Architecture in the Age of Divided Representation: The Question of Creativity in the Shadow of Production. The MIT Press, Cambridge and London. 